\title{
高分子材料の官能基構造の影響にみる 粘着血小板形態の電顕的解析
}

\author{
阿部 一彦* 関口 守衛** 片岡 一則*** 岡野 光夫*** \\ 桜井 靖久 $* * *$ 鶴田 禎二**** 丸山 厚****
}

\section{Morphological analysis of platelets adhering to polymer surfaces with functional groups: A scanning and transmission electron-microscopic study}

\author{
Kazuhiko ABE*, Morie SEKIGUCHI**, Kazunori KATAOKA***, \\ Teruo OKANO***, Yasuhisa SAKURAI***, Teiji TSURUTA**** \\ and Atsushi MARUYAMA****
}

\section{Key words: nonionic polymer, cationic polymer, albumin coating, platelet adhesion, electron-microscopy}

Progress in implantable artificial organs such as the artificial heart, artificial vessele and the artificial kidney depends greatly on the development of excellent antithrombogenic materials because prevention of thrombosis is indispensable for the successful utilization of these artificial organs. In order to design excellent antithrombogenic materials, it is important to clarify the effects of the functional groups of the material surfaces on the surface-induced activation of platelets.

For this purpose, poly(styrene)(PSt)(nonionic, hydrophobic polymer), and poly (p-dimethylaminoethylstyrene) (PMAS) (weakly cationic polymer) were prepared, and the adhesion of rat platelets to these polymer surfaces was examined. Albumin-coated as well as non-coated polymer surfaces were used in this experiment.

* 東京女子医科大学日本心臓血圧研究所理論外科 [₹162 東京都新宿区河田町 8-1], Department of Surgical Science, The Heart Institute of Japan, Tokyo Women's Medical College, Tokyo, Japan.

** 同循環器内科, Department of Cardiology, The Heart Institute of Japan, Tokyo Women's Medical College, Tokyo, Japan.

*** 同医用工学研究施設, Institute of Biomedical Engineering, Tokyo Women's Medical College, Tokyo, Japan.

**** 東京理科大学工学部工業化学科, Department of Industrial Chemistry, Faculty of Engineering, Science University of Tokyo, Japan. 受付 : 1987.2.13. 受理 : 1987.11.19. 
Platelets were collected from 5 rats by cardio-puncture, and were suspended in Hanks' balanced salt solution $\left(\mathrm{Ca}^{2+}, \mathrm{Mg}^{2+}\right.$ free $)$. The interaction of the platelets thus prepared with the polymer surfaces was studied by the microsphere column methed at $4{ }^{\circ} \mathrm{C}$ and at room temperature. The morphological changes of the adhering platelets on the polymer surfaces were observed by scanning (SEM) and transmission electron-microscopes (TEM).

Platelets adhered to the albumin-coated as well as non-coated PMAS surfaces at room temperature; they were rough-surfaced, round in shape with a few long pseudopods. TEM observation revealed that the platelets on these PMAS surfaces had retained more organella such as $\alpha$-granules than those on the noncoated PSt surface, which had a spreading form. Rounded platelets were observed on the PSt surface with albumin-coating. Similar results were obtained for experiments done at $4^{\circ} \mathrm{C}$. Despite their distinct morphology, there was no significant difference in the percent retention of platelets between PSt and PMAS.

Thus, it is suggested that cytological changes of the platelets do not always coincide with adhesivity of the platelets to the material surface. Consequently, this study revealed that the albumin-coated as well as non-coated PMAS surfaces with a weakly cationic amino group have a high adhesivity to platelets but have lower tendency to activate platelets than the nonionic non-coated PSt surface.

\section{緒言}

優れた抗血栓性高分子材料の開発は臨床医学 の場に扔いて大きな期待が寄せられて特り，人 工心臓, 微小口径人工血管などの循環系人工蔵 器, 並びに人工肝蔵, 人工膵蔵などの代謝系人 工蔵器などがその対照となる。しかし, 抗血栓 性材料の分子設計の指針はいまだ十分に確立さ れていないのが現状である. 抗血栓性は材料表 面層の化学的あるいは物理的性質に大きく影響 されることからその設計指針を確固たるものに するためには, 化学的あるいは物理的に修飾し た多くの材料表面層と血液細胞，とりわけ血小 板との相互作用を明確にすることが重要とな る.

今回，ノニオン系とノニオン系に弱カチオン 性の第 3 級アミノ基を官能基として導入した高 分子材料表面，そしてそれぞれにアルブミンを 吸着させた材料表面に粘着した血小板の形態変 化を走查電顕 (SEM) そて, 内部構造変化を透 過電顕 (TEM) 飞て比較解析し, 血小板機能に 及ぼす官能基の構造の影響について検討したの で報告する。

\section{I. 方 法}

（1）実験に用いた高分子材料（図 1)：ノ= オン系で疎水性の均一表面を有するポリスチレ ン (PSt) とスチレン $(\mathrm{St})$ に弱カチオン性のジ メチルアミノェチル基 $\left(-\mathrm{CH}_{2}-\mathrm{CH}_{2}-\mathrm{N}<\mathrm{CH}_{3}\right)$

を導入したポリジメチルアミノェチルスチレン (PMAS)，そしてそれぞれの材料表面に $1 / 5$ 生理濃度のラットアルブミン（シグマ社・フラ クションV) を吸着させた 4 種類のポリマービ ーズ $(\phi 150 \mu \mathrm{m})$ を準備し実験に用いた.

(2) 粘着血小板の形態変化および 内部構造 変化の SEM, TEM による解析：(1)各ポリマ ービーズをポリ塩化ビニル製のチューブ（長さ $2 \mathrm{~cm}$; 内径 $3 \mathrm{~mm}$ ) に最密充填した. (2) 5 匹の ウィスターラット $(350 \mathrm{~g}, \hat{\mathrm{o}})$ を用い, 血液 9 容に対して $3.8 \%$ クエン酸ナトリウムを 1 容の割合で含ませたディスポーザブルシリンジ に心蔵穿刺により採血した。直ちにFスピッツ 管に分注し, $4{ }^{\circ} \mathrm{C} 800$ r.p.m. で20分間, さらに 上澄みを $4{ }^{\circ} \mathrm{C} 2000$ r.p.m. で 15 分間遠心処理 後, 下層の血小板を $\mathrm{Ca}^{2+}, \mathrm{Mg}^{2+}$ free の Hanks' balanced salt solution ${ }^{1)}(\mathrm{pH} 7.4)$ で $1 \sim 3 \times$ 
(1)

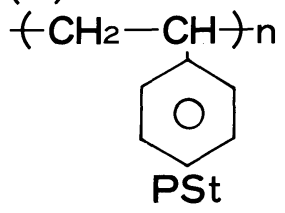

(2)

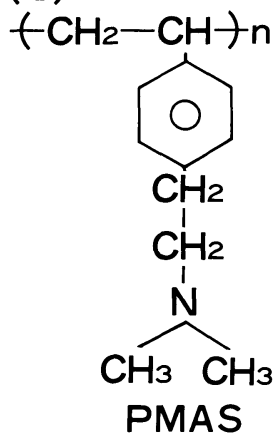

Fig. 1 Chemical structures of polymers examined

(1) poly (styrene)(PSt) (nonionic, hydrophobic polymer)

(2) poly (p-dimethylaminoethyl styrene)(PMAS) (weakly cationic polymer)

$10^{11}$ コ/l の血小板浮遊液に調製した. (3)マイク ロスフィアカラム法2)を用い, (2)で調製した血 小板浮遊液をディスポーザブルシリンジに採取 し，(1)で調製したチューブに室温と室温の対照 群としての $4{ }^{\circ} \mathrm{C} と に$ 分けた状態で, 血小板を流 速 $0.5 \mathrm{ml} /$ 分で 1 分間流し, 5 分間浸漬した. (4) ビーズをカラムから取り出し $3 \%$ グルタールア ルデヒド・0.1 Mリン酸緩衝溶液 $(\mathrm{pH} 7.4)$ と $1 \% \mathrm{OsO}_{4}$ millonig 溶液 ( $\left.\mathrm{pH} 7.4\right)$ での二重固 定後, エチルアルコール系列脱水などの SEM,

TEM 観察のための常法処理を行い, 高分子材 料に導入した官能基の構造の影響にみる粘着血 小板の形態変化を SEM(HHS- 2 R 型・加速電 圧 $25 \mathrm{kV}$ ) そて, 内部構造変化を TEM (JEM $1200 \mathrm{EX}$ 型・加速電圧 $80 \mathrm{kV}$ ) にて解析した.

（3）血小板停滞率の比較: 各ポリマービー バを最密充填したカラム中への血小板の流出前 後の血小板数を Coulter Counter (ZBI 型) に て数光，その值をもとに各ポリマー素表面とア ルブミンを吸着させた表面に対する血小板の停 滞率を算出し比較検討した。

\section{II. 結 果}

（1） ポリマー素表面とアルブミン吸着表面 に対する血小板停滞率の比較（図 2)：[室温に 招ける比較]室温飞扔ける血小板停滞率は未コ ートPSt で $68.45 \pm 6.33 \%$ であるのに対して,

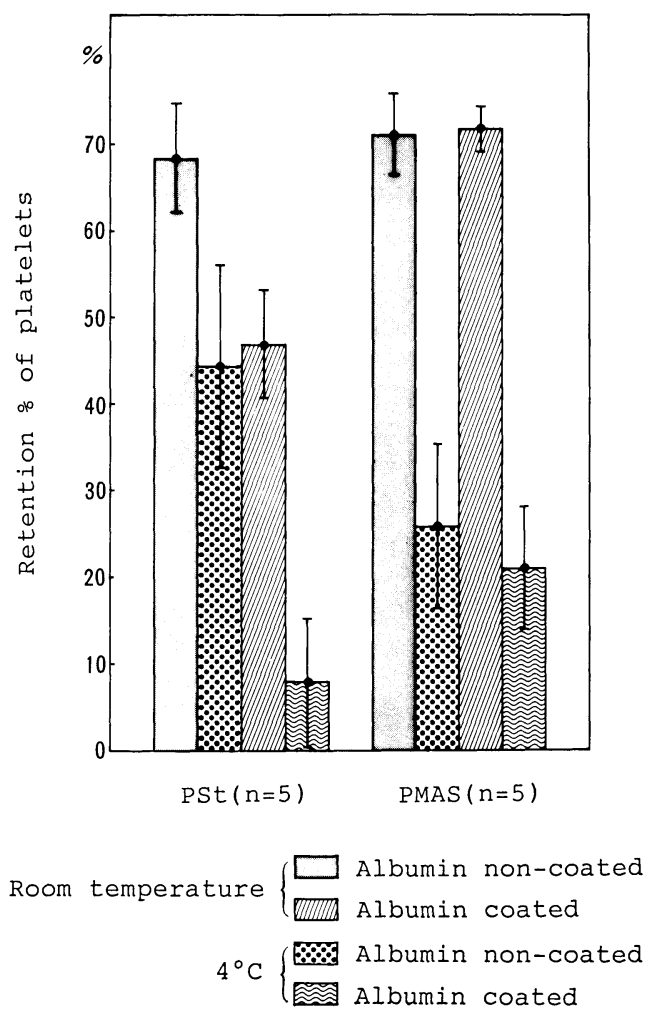

Fig. 2 Retention $\%$ of rat platelets on polymer surfaces with or without albumin-coating

アルブミンコート PSt では $46.88 \pm 6.27 \%$ で あり，PStにアルブミンを吸着させることによ って血小板の停滞率が抑制された。 また未ュー ト PMAS に抢ける血小板停滞率は71.07士4.82 \%であり，アルブミンコート PMAS に执いて は $71.69 \pm 2.59 \%$ であった. PMAS に抏いて は素表面, アルブミン吸着表面に叔ける血小板 停滞率に汪とんど差はなかった。【低温 $\left(4{ }^{\circ} \mathrm{C}\right)$

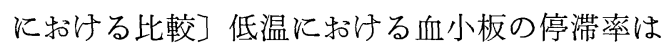
未コートPSt に执いて $44.17 \pm 11.59 \%$ である のに対してアルブミンコート PSt では 7.74士 $7.48 \%$ であり室温での結果と同様に PSt にア ルブミンを吸着させることによって血小板の停 滞率が抑制された。一方，未コート PMAS に 特ける血小板の停滞率は2 $5.77 \pm 9.43 \%$ であり,

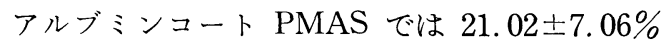
であった. PMAS の素表面, アルブミン吸着 表面に打いては室温と同様に低温に打沙血小 


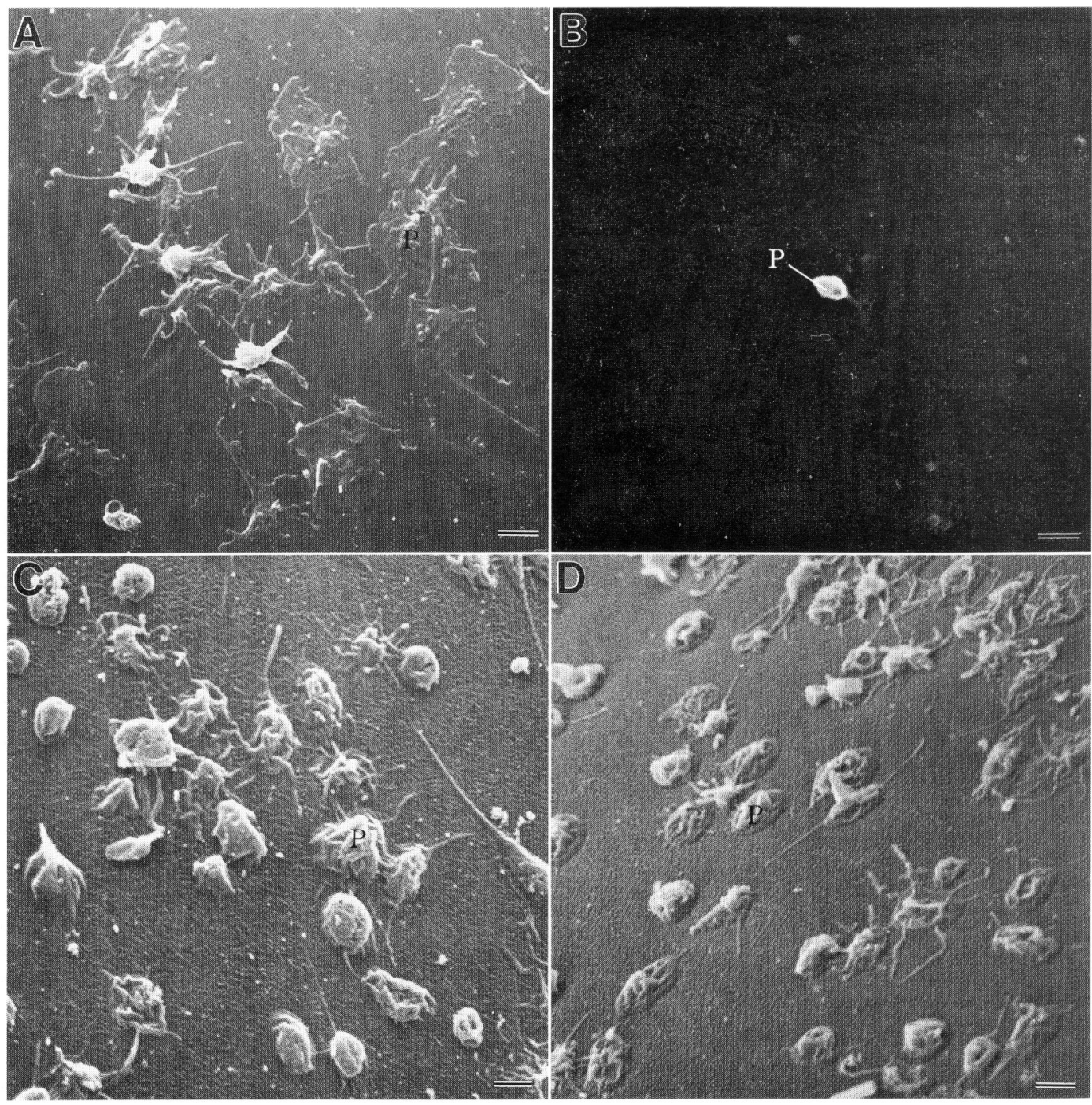

Fig. 3 Scanning electron micrographs of rat platelets adhered to polymer surfaces at room temperature A : Albumin non-coated PSt, B : Albumin coated PSt,
C : Albumin non-coated PMAS, $\quad$ D : Albumin coated PMAS.

$\mathrm{P}$ : Platelet $\quad *$ The bars in each figure indicate $1 \mu \mathrm{m}$.

板の停滞率に有意差はなかった.

（2） SEM によるポリマー素表面とアルブ ミン吸着表面に粘着した血小板の形態变化の比 較：[室温に拾ける比較（図 3)]末コートPSt 表面に粘着した血小板は伸展形をしたものが多 く観察された。ささらに伸展した血小板のその胞 体同士が連絡した凝集像も観察された。一方， アルブミンをコートしたPSt 表面に粘着した血 小板以その数が極めて少なかったが，観察され た血小板は偽足の短い表面の滑らかな球状形を
呈していた. また未コートPMAS 表面に粘着 した血小板は長い偽足を突出し，表面に叫凸の ある球状形として観察された。 さらに他の血小 板の偽足と連絡している凝集像も観察された. また，アルブミンをコートした PMAS 表面に 粘着した血小板の形態変化は未コート PMAS 表面でのそれと同程度であった。 [低温 $\left(4{ }^{\circ} \mathrm{C}\right.$ )

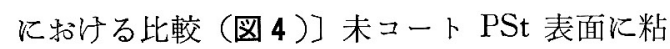
着した血小板はSpiny な偽足を突出した球状 形のものが多く観察された。 また，アルブミン 


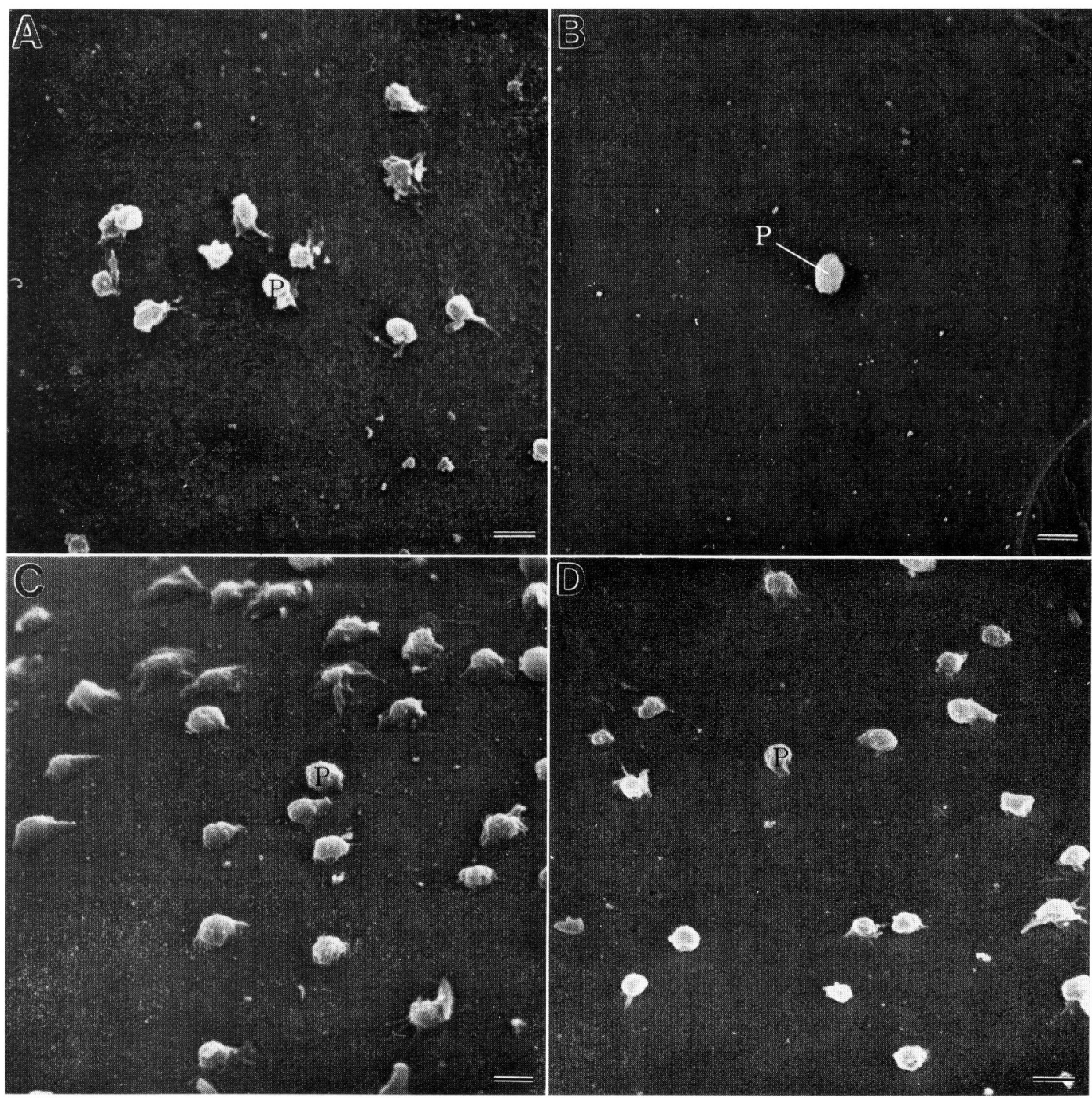

Fig. 4 Scanning electron micrographs of rat platelets adhered to polymer surfaces at $4^{\circ} \mathrm{C}$

A : Albumin non-coated PSt, B : Albumin coated PSt,

C : Albumin non-coated PMAS, D : Albumin coated PMAS.

$\mathrm{P}:$ Platelet $\quad *$ The bars in each figure indicate $1 \mu \mathrm{m}$.

をコートした PSt 表面に粘着した血小板は球 状形として観察された．未コートPMAS 表面 に粘着した血小板は表面の滑らかな偽足の短 い球状形のものが多く観察された。また，アル ブミンをコートした PMAS 表面に粘着した血 小板の形態变化は未コートPMAS と同程度で あった。

（3）TEM によるポリマー素表面とアルブ ミン吸着表面に粘着した血小板の内部構造变化 の比較：〔室温に打汀る比較（図５）〕未コート
PSt 表面に粘着した血小板内には微小系 (MF) が観察され，濃染顆粒 (DB), 特殊顆粒 $(\alpha \mathrm{G})$ などの貯蔵顆粒は放出した像として観察され た。 なたアアルブミンをコートした PSt 表面 に粘着した血小板については粘着数が少ないた め注まだ TEM にてとら党ることはできてい ない，一方，未コート PMAS に粘着した血小 板内には MF は観察されるものの未ュート PSt 表面に粘着した血小板に比べて $\alpha \mathrm{G}$ のなどオル ガネラは比較的保持されていた。 また，アルブ 
A

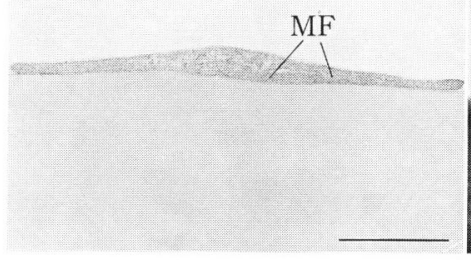

B

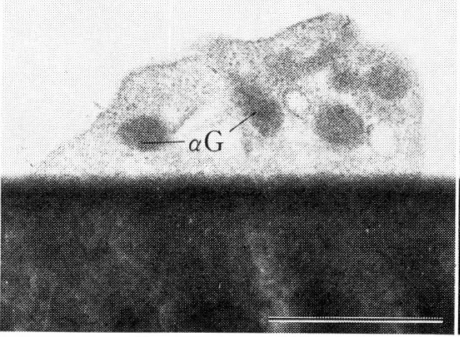

C

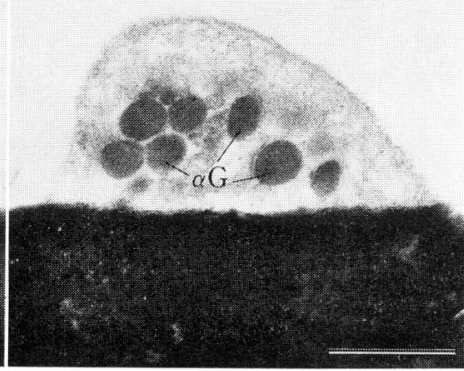

Fig. 5 Transmission electron micrographs of rat platelets adhered to polymer surfaces at room temperature

A : Albumin non-coated PSt, B : Albumin non-coated PMAS,

C : Albumin coated PMAS.

$\alpha \mathrm{G}: \alpha$-granule

$\mathrm{MF}:$ microfilament

* The bars in each figure indicate $1 \mu \mathrm{m}$.

A

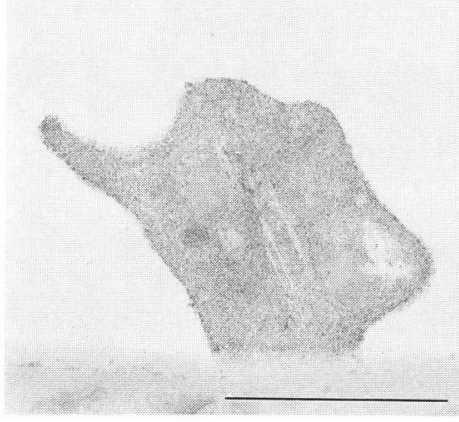

B

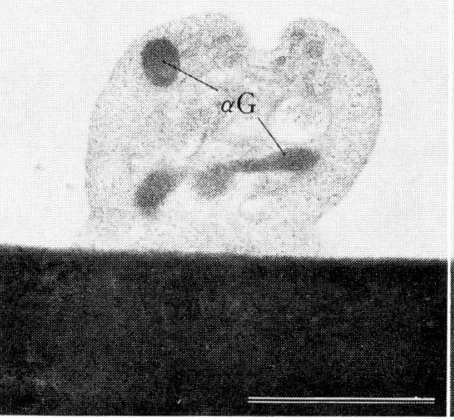

C

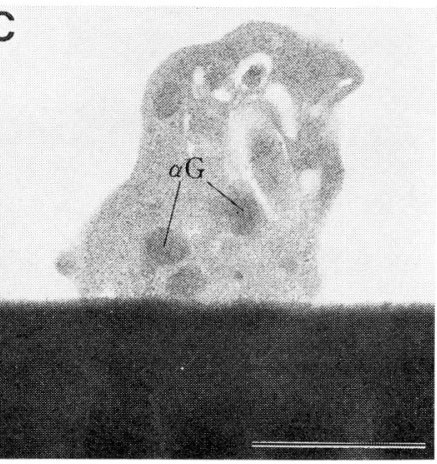

Fig. 6 Transmission electron micrographs of rat platelets adhered to polymer surfaces at $4^{\circ} \mathrm{C}$
A : Albumin non-coated PSt,
B : Albumin non-coated PMAS,

$\mathrm{C}:$ Albumin coated PMAS.

$\alpha \mathrm{G}: \alpha$-granule

* The bars in each figure indicate $1 \mu \mathrm{m}$.

ミンをコートした PMAS 表面に粘着した血小 板の内部構造変化は未コート PMAS 表面での ものと同程度であった。 〔低温 $\left(4^{\circ} \mathrm{C}\right)$ 飞和ける 比較（図 6 )] 未ュート PSt 表面に粘着した血 小板内では MF と脱顆粒が観察された。 また, アルブミンをコートしたPSt 表面に和いては室 温時と同様に粘着している血小板数が少ないた めにいまだ TEM にてとらえることはできてい ない,一方, 未コート PMAS 表面に粘着した 血小板は未コートPSt に粘着した血小板に比べ て $\alpha \mathrm{G}$ などのオルガネラは比較的保持されてい た. なた，アルブミンをコートした PMAS 表 面に粘着した血小板の内部構造変化は未コート
PMAS 表面での場合と同程度であった。

\section{III. 考 察}

近年, $\mathrm{FDA}$ (アメリカ食品医薬品局)の認可に より数例の患者に対して完全人工心臓 (Jarvik7 型) の移植が行われたが，注とんどの例にお いて血栓形成の問題を生じ抗血栓性材料に関す る基礎研究の重要性が強く印象づけられた ${ }^{32}$.

信頼できる抗血栓性材料の開発に沶いて重要 なことは様々な化学的及び物理的性質をもつ材 料表面層と血液細胞, 特に血小板との相互作用 を明確にして, 抗血栓性材料の分子設計に際し ての作業理論を築き上げていくことである. 
そのためには血小板の生理的機能を十分に把 握することが必要となる，特に血小板膜は外界 との相互作用のすべてを媒介して抢り，血小板 活性化の中心的な役割を担っている4). また粘 着と凝集の部位と考光られている5).

血小板の表面活性化に伴ら形態変化は MF の 再構成による 微小管 (MT) のゆがみによって 生じることが知られている ${ }^{6)}$. この形態変化の 過程に执いて, 血小板は平円盤形から球状形, 偽足を伴う膨隆, さらに伸展形へと変化し, これに開放小管系 (OCS) の拡大, $\mathrm{DB} \cdot \alpha \mathrm{G} な$ ぞの貯蔵顆粒の放出を伴う。また, 球状形と伸 展形の血小板とでは MF の再構成の度合が異な って掠り, 不可逆的に付着を強固にしている伸 展形の血小板はMFが細胞質内で高密度にネッ トワークを形成していることが高圧電顕によっ て明らかにされている7).

1977年に Falb，R.D はノニオン系の PSt ビ 一ズにー $\mathrm{NH}_{2}$ 基, $-\mathrm{SO}_{3} \mathrm{H}$ 基, $-\mathrm{NO}_{2}$ 基などを 付着させたものと PRP (多血小板血漿), PPP （乏血小板血漿）との相互作用の実験を行い, 一 $\mathrm{NH}_{2}$ 基を付着させた PSt 表面が血小板に最 も強い影響を示し, 多くの血小板がこの表面に 吸着し, 顕著な血小板破壊を生じたと報告して いる8). しかし Falb はこの表面に吸着した血 小板の形態ならびに内部構造の解析は試みては いない.

今回, 我々はノニオン系の PSt と St に弱力 チオン性の第 3 級アミノ基（ジメチルアミノェ チル基）を導入した PMAS，そしてそれぞれ にラットアルブミンをコートした 4 種類のポリ マービーズと $\mathrm{Ca}^{2+}, \mathrm{Mg}^{2+}$ free の Hanks' balanced salt solution ${ }^{1)}(\mathrm{pH} 7.4)$ にて調製したラ ット血小板浮遊液との相互作用をマイクロスフ ィアカラム法2)を用いて室温ならびに室温の対 照群としての $4{ }^{\circ} \mathrm{C} に て$ 行い, 血小板の停滞率, 形態変化, 内部構造変化に着目して解析した.

血小板の停滞率に関しては，ノニオン系の PSt と St に弱カチオン性のジメチルアミノェ チル基を導入した PMAS，そしてアルブミン をコートした PMAS 表面はいずれも血小板を 多く吸着したが，ノニオン系の PSt 表面にアル ブミンをコートすることによって血小板の吸着
が抑制された。特に，ここで注目すべさことは PSt と PMAS 表面に同じラットアルブミンを コートしたにもかかわらず血小板停滞率に顕著 な差を生じたことであるが，これは，カチオン 性のポリマー表面にコートしたアルブミンはノ ニオン系のポリマー表面にコートしたそれより

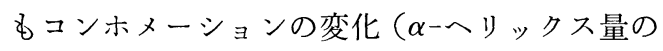
減少）が大きいことに起因しているものと考光 られる ${ }^{910)}$. この血小板吸着量と $\alpha$-ヘリックス 量とに負の相関性があることは荷電状態を制御 したポリイオンコンプレックス膜を用いた実験 によって示されている10).

また形態変化, 内部構造変化に関しては, 未 コート PMAS 表面に粘着した血小板は長い偽 足を突出して表面の凹凸のある球状形の血小板 として観察され，そのオルガネラは伸展形をし て未コート PSt 表面に粘着した血小板のオルガ ネラに比較して良く保持されていた. このこと は血小板の粘着の強さと血小板の内部構造変化 とは必ずしも一致しないことを示唆している. また,アルブミンコートしたPMAS 表面に粘着 した血小板は未コートPMAS 表面での所見と 同程度であったが，血小板停滞率の最も低かっ たアルブミンコートPSt 表面に粘着した血小板 は球状形を呈して扣り，4種類のポリマーの中 で最も活性化が弱いことを示していた．しかし この血小板内のオルガネラはいまだ TEM にて とらえられていない.このようなアルブミンコ ート PMAS 表面, アルブミンコート PSt表面 に粘着した血小板の形態変化の違いは弱カチオ ン性の第 3 級アミノ基を有する PMAS 表面に コートしたアルブミンのコンホメーション変化 ( $\alpha$-ヘリックス量の減少)はノニオン系のPSt表 面にコートしたアルブミンの変化より大さいこ とを示唆するものである.また, 未コートPMAS 表面，アルブミンコート PMAS 表面は未コー ト PSt 表面に比べて粘着血小板の形態変化, 内 部構造変化を抑制していたが，このことは血小 板膜の糖蛋白 (GP) の集合規制による MF の再 構成の抑制に起因する可能性も考兄られる ${ }^{11}$. この根拠として血小板膜の GP, 特に GP Ib, GPII b/IIIa は膜貫通性の GP であり, 非刺激 血小板に执いてこの $\mathrm{GP} \mathrm{Ib}^{1213)}$ はアクチン結 
合蛋白を介して, GPII b/ $/ I \mathrm{a}^{14)}$ は直接膜直下に 存在する MF と結合していると考兄られてい る. また, 血小板の形態変化は MF の再構成に

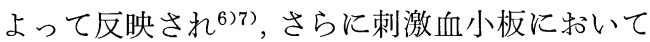
GPIb, GPIIb/IIIa はクラスターを形成する ことが免疫電顕によって明らかにされている ${ }^{15)}$ ことなどがあげられる。

以上のことから, St に弱カチオン性の第 3 級アミノ基（ジメチルアミノェチル基）を導入 した PMAS 表面は血小板に対して高い結合能 を有するが，血小板の活性化はノニオン系の PSt 表面に比較して抑制されることが明らかに なった。このことは，高分子材料表面に適当な 官能基を導入することによって血小板の粘着挙 動を制御することが可能であることを示唆する ものである。また，同じアルブミンをコートし た PSt，PMAS 表面に粘着した血小板はとれ ぞれ異なった粘着挙動を呈したことから，アル ブミンは官能基の構造を認識したコンホメーシ ョン変化をとり，さらに血小板はこのようなコ ンホメーションの異なるアルブミンを認識した 粘着挙動をとることが示唆される.

本研究を通じて，より優れた抗血栓性高分子 材料を開発するためには，材料生化学 ${ }^{16)}$ 基盤 として血液細胞，特に血小板と様々な物理的及 び化学的性質を持つ材料表面層との解析を推進 していくことの重要性が示唆された.

\section{まと め}

ノニオン系の PSt と St に弱カチオン性の 第 3 級アミノ基であるジメチルアミノェチル基 （官能基）を導入した PMAS，そしてそれぞれ にラットアルブミンをコートした 4 種類のポリ マービーズ ( $\phi 150 \mu \mathrm{m})$ 表面に対するラット $(n=5)$ 血小板の停滞率並びにこれらの材料表 面に粘着した血小板の形態変化と内部構造変化 についてマイクロフィアカラム法を用いて比較 解析し，血小板機能に及ぼす官能基の構造の影 響について検討した。

それによると, St に第 3 級アミノ基を導入 した PMAS 表面はアルブミンコートの有無に かかわらず血小板に対して高い結合能を有して いたが，血小板の活性化 (形態変化, 内部構造
変化）はノニオン系の未コート PSt 表面に比 べて抑制されることが明らかになった。

以上の事実から，材料表面に対する血小板の 粘着性と粘着血小板の内部構造変化とは必ずし も一致しないことが示唆された. また, 血小板の 粘着挙動は材料表面に適当な官能基を導入する ことによって制御できる可能性が示唆された。

\section{文献}

1) Hanks, J.H. and Wallace, R.E.: Relation of oxygen and temperature in the preservation of tissues by refrigeration. Proc. Soc. Exp. Biol. Med., 71; 196 200, 1949.

2) Sakurai, Y., Akaike, T., Kataoka, K. and Okano, T.: Interfacial phenomena in biomaterials chemistry (ed. Goldberg, E.P., et al.: Biomedical polymers), Academic Press, New York and London, 1980, p.335 375.

3) Relman, A.S.: Artificial hearts-permanent and temporary. N. Engl. J. Med., 314; 644 645, 1986.

4) Coller, B.S.: Disorders of platelets (ed. Ratnoff, O.D. et al.: Disorders of hemostasis), Grune \& Stratton, Inc., New York and London, 1984, p. $73 \sim 176$.

5) White, J.G.: Ultrastructural defects in congenital disorders of platelet function. Ann. N. Y. Acad. Sci., 201; 205 233, 1972.

6) Debus, E.,Weber, K. and Osborn, M.: The cytoskeleton of blood platelets viewed by immunoluorescence microscopy. Eur. J. Cell. Biol., 24; 45 52, 1981.

7) Loftus, J.C., Choate, J. and Albrecht, R.M.: Platelet activation and cytoskeletal reorganization-high voltage electron microscopic examination of intact and triton-extracted whole mounts. J. Cell. Biol., 98; 2019 2025, 1984.

8) Falb, R.D., Leininger, R.I. and Crowley, J. P.: Materials with chemically active substituents. Ann. N.Y. Acad. Sci., 283; 396 403, 1977.

9）赤池敏宏, 桜井靖久, 小菅一弘, 仙波義彦, 桑名克之, 宮田清蔵, 片岡一則, 鶴田禎二: 円二色性 - 紫外吸収スペクトルによるポリイ オンコンプレックスと血漿タンパク質の相互 作用の解析. 高分子論文集, 36；217 222, 


\section{9.}

10）赤池敏宏, 桜井靖久: 医用高分子材料の化学. 化学の領域, 34；519～527，1980.

11) Kataoka, K., Okano, T., Sakurai, Y., Nishimura, T., Maeda, M., Inoue, S., Shinohara, I., Akaike, T. and Tsuruta, T.: Development of new biomaterials for blood cell separator. Artificial Organs, 5 (Suppl.); 532 539, 1981.

12) Okita, J.R., Pidard, D., Newman, P.J., Montgomery, R.R. and Kunichi, T.J.: On the association of glycoprotein $\mathrm{Ib}$ and actin-binding protein in human platelets. J. Cell. Biol., 100; 317 321, 1985.

13) Fox, J.E.B.:Identification of actin-binding protein as the protein linking the membrane skeleton to glycoproteins on platelet plasma membranes. J. Biol. Chem., 260; 11970 11977, 1985.

14) Wu, MP. and Stracher, A.: Partial reconstruction of the platelet membrane-cytoskeleton complex. Nouv. Rev. Fr. Hematol., 27; 219 〜221, 1985.

15) Polley, M.J., Leung, L.L.K., Clark, F.Y. and Nachman, R.L.: Thrombin-induced platelet membrane glycoprotein II b and III a complex formation. J. Exp. Med., 154; 1058 1068, 1981.

16）桜井靖久, 赤池敏宏 : 医用高分子と生体との 反応の解析一材料生化学へのアプローチ(医用 高分子), 共立出版, 東京, 1978, p.151 196. 